\title{
Karakterisasi Sensori Cheese Tea dengan Metode Check All That Apply (CATA), Emotional Sensory Mapping (ESM), dan Ideal Profile Method (IPM)
}

\section{Sensory Profiling of Cheese tea profiling using Check All That Apply (CATA), Emotional Sensory Mapping (ESM), and Ideal Profile Method (IPM)}

\begin{abstract}
Dase Hunaefi ${ }^{1,2)} *$ dan Ziyad Muhammad Farhan ${ }^{1)}$
${ }^{1)}$ Departemen Ilmu dan Teknologi Pangan, Fakultas Teknologi Pertanian, Institut Pertanian Bogor, Bogor

${ }^{2)}$ South East Asian Food and Agricultural Science and Technology (SEAFAST) Center, Institut Pertanian Bogor, Bogor

Abstract. Cheese tea is a drink made from a combination of tea and cheese foam. This product is very popular today, and some businesses are interested in developing this product. The objective of this research is to identify the sensory profile of cheese tea through new methods in sensory evaluation: IPM, CATA and ESM. The CATA method is used to define the sensory profile and emotional characteristics of the cheese tea product and the IPM method is used to optimize the product by collecting the ideal customer information. The number of panelists used for each test was 30. The selection was based on the frequency of cheese tea consumption 1 to 2 times per week. Attributes will be gained via the focus group discussion (FGD). CATA data analysis was processed using XLSTAT software with CATA Analysis tools while IPM data was processed with SensTools.Net applications with tools for IPA analysis. The cheese tea products most favored by customers based on the outcome of the CATA are products with a sweet scent, a milky aroma, cheesy aroma, a milky taste and a sweet taste, as well as the dominant emotional 'calm'. Product cheese tea $C$ is the nearest product to its ideal product characteristics. In order to further improve the product "cheese tea C", it is necessary to boost the strength of the characteristics of the creamy mouthfeel, the viscosity of the mouthfeel and the aroma of the cheese while at the same time reducing the intensity of the toasted aroma, the milky aroma, the umami, the salty taste, the milky taste and the sweet taste.
\end{abstract}

Keywords: cheese tea, check all that apply (CATA), emotional sensory mapping (ESM), ideal profiling method (IPM), sensory evaluation

\begin{abstract}
Abstrak. Produk kekinian yang sedang menjadi tren adalah cheese tea. Produk ini adalah perpaduan teh dan keju. Keunikan rasanya mengakibatkan perusahaan minuman juga tertarik untuk mengembangkan produk tersebut secara industri. Tahapan awal dari pengembangan industrialisasi adalah karakterisasi produk. Tujuan dari penelitian ini adalah mengidentifikasi atribut organoleptik dari produk cheese tea dengan menggunakan metode uji sensori terbaru yaitu check all that apply (CATA), emotional sensory mapping (ESM), dan ideal profiling method (IPM). Setelah dilakukan seleksi konsumen, tiga puluh konsumen terpilih untuk menjadi panelis setiap pengujian diatas. Seleksi pemilihan panelis didasarkan pada frekuensi produk cheese tea 1-2 kali dalam seminggu. Penentuan atribut sensori dan emosi yang digunakan dalam pengujian ditentukan melalui focus group discussion (FGD). Data yang diperoleh dari hasil pengujian CATA dan ESM diolah dengan XLSTAT, namun untuk pengolahan data IPM dilakukan dengan aplikasi SensTools.Net. Hasil CATA, cheese tea yang memiliki karakter aroma manis, aroma susu, aroma keju, rasa susu dan rasa manis dengan atribut emosi tenang menjadi produk yang disukai oleh konsumen. Hasil pengujian ideality cheese tea $\mathrm{C}$ adalah produk yang paling mendekati karakteristik ideal. Analisis lanjutan optimasi produk cheese tea $\mathrm{C}$ dengan IPM menunjukkan bahwa tingkat creamy mouthfeel, kekentalan dan aroma keju perlu ditingkatkan, namun aroma panggang, aroma susu, gurih (umami), rasa asin, rasa susu dan rasa manis harus diturunkan intensitasnya.
\end{abstract}

Kata kunci: cheese tea, check all that apply (CATA), emotional sensory mapping (ESM), evaluasi sensori, ideal profiling method (IPM)

\footnotetext{
Aplikasi Praktis. Pengujian karakterisasi organoleptik dengan metode baru dalam uji sensori bisa memberikan gambaran karakteristik sensori dengan keunikan emosi didalamnya pada produk cheese tea yang disukai konsumen. Hasil penelitian ini dapat digunakan oleh industri makanan untuk cheese tea misalnya produk cheese tea siap minum (ready-to-drink) yang diinginkan konsumen.
} 


\section{PENDAHULUAN}

Cheese tea adalah produk olahan teh dengan konsep baru yang berasal dari Taiwan. Produk ini dibuat dengan menggabungkan teh dengan cheese foam. Rasa teh yang manis dan rasa keju yang gurih menjadi perpaduan yang unik. Ada berbagai varian cheese tea seperti cheese tea hitam, keju macha, cheese tea thai, cheese tea melati, dan lain-lain. Saat ini, cheese tea tidak hanya populer di Taiwan, tetapi juga berbagai negara lain di Asia Tenggara, bahkan Inggris dan Amerika Serikat. Cheese tea cukup populer di kalangan anak muda belakangan ini. Di kota-kota besar di Cina, beberapa waralaba teh menjual rata-rata 1000 cangkir cheese tea per hari. Minuman ini sangat populer di Jepang sehingga perusahaan minuman Jepang Kirin berencana untuk membuat versi botol (Tseng 2018). Kualitas organoleptik tentunya tidak dapat dilepaskan pada proses pengembangan produk dan kontrol kualitas produk makanan dan minuman. Analisis sensorik adalah metode untuk memberikan informasi tentang kualitas produk makanan (Rahmawati et al. 2015).

Sebuah tantangan bagi perusahaan atau produsen untuk dapat mengembangkan produk cheese tea dengan karakteristik yang diminati oleh konsumen (Varela et al. 2010). Fase pertama dari pengembangan produk baru adalah mengkarakterisasi atau memetakan atribut produk yang ada dipasaran. Pemetaan karakter produk yang ada di pasaran digunakan sebagai bahan dasar pengembangan produk baru dengan mencari atribut sensori yang disukai dan di persepsi ideal oleh konsumen dari kategori produk tersebut. Jika hanya menggunakan uji kesukaan atau biasa disebut dengan uji hedonik, tidak memenuhi informasi karakter apa yang disukai oleh konsumen (Faye et al. 2006). Uji penerimaan dengan uji hedonik saja pun tidak memberikan data terkait persepsi ideal yang terbentuk di masyarakat atau konsumen terkait dengan kategori produk yang diujikan. Oleh sebab itu, untuk mencari pemetaan atribut yang disukai dan yang dipersepsi sebagai atribut ideal, harus menggunakan uji sensori dengan metode relatif baru di Indonesia yaitu CATA (Ares et al. 2010) dan Ideal Profile Method (IPM). Metode ini merupakan solusi ketika perusahaan menghadapi kesulitan menemukan panel terlatih. Pertanyaan dalam metode CATA terdiri dari kata atau frasa yang kemudian dipilih oleh panel untuk menggambarkan produk (dilambangkan dengan "1" untuk menunjukkan ada atribut sensorik yang diuji dan "0" jika tidak ada atribut sensorik yang diuji dalam sampel) (Dooley et al. 2010; Reinbach et al. 2014).

Informasi mengenai perasaan atau emosi ketika mengonsumsi produk tersebut sangatlah penting disebabkan memberikan informasi terkait interaksi antara konsumen dengan produk yang dinikmatinya (Worch et al. 2010). Tentunya atribut sensori memberikan korelasi terkait emosi yang dihasilkan ketika mengonsumsi suatu produk (Meiselman 2015). Pengalaman emosi ketika berinteraksi dengan produk memberikan masukkan bagi industri pangan untuk memberikan input atribut apa yang menumbuhkan emosi yang positif dan atribut apa yang memberikan perasaan negatif sehingga bisa mengurangi kesukaan dari sebuah produk. Emotional sensory mapping (ESM) digunakan untuk memberikan gambaran emosi apa yang dihasilkan dan korelasinya atribut sensori.

Sebagai catatan, pemetaan terkait emosi yang dihasilkan ini sangat jarang di Indonesia di lakukan dan ini merupakan salah satu tulisan pertama yang mengungkap korelasi atribut dan emosi yang ditimbulkan. Beberapa studi menyebutkan bahwa profiling emosi dapat memberikan informasi tambahan disamping penerimaan sensori produk pangan. Emosi juga dapat memengaruhi keputusan dalam pembelian produk (Jiang et al. 2014) Emosi positif dapat memberikan nilai tambah pada produk dan emosi negatif di sisi lain dapat menurunkan nilai produk. Emosi konsumen terhadap suatu produk dapat dibentuk melalui faktor-faktor eksternal seperti iklan dan pengemasan dan melalui faktor-faktor internal seperti profil sensoris suatu produk (Thomson et al. 2010).

Ideal Profile Method (IPM) adalah analisis deskriptif yang dilakukan oleh konsumen yang pada kuisionernya terdapat pertanyaan tambahan tentang intensitas dan kesukaan ideal dari produk (Worch et al. 2012). Setiap konsumen menilai serangkaian produk dan menilai setiap produk pada atribut sensori yang sama (Worch dan Punter 2014). Setiap atribut, baik intensitas yang dirasakan maupun ideal dinilai pada jenis skala yang sama yaitu skala $100 \mathrm{~mm}$. Jadi, jika pertanyaan pertama adalah: 'Silakan beri penilaian terhadap intensitas manis produk ini', maka pertanyaan kedua adalah: 'Silakan beri penilaian terhadap intensitas manis ideal pada produk ini'. Metodologi ini telah diadopsi dengan tujuan untuk meniru skala JAR, tetapi menggunakan intensitas yang dirasakan dan ideal alih-alih perbedaan dengan ideal yang dibayangkan (Worch dan Punter 2014).

Penelitian tentang evaluasi sensori dan profiling emosi cheese tea sangat terbatas dan merupakan hal baru, seiring trend cheese tea yang baru masuk ke pasaran Indonesia. Penelitian ini bertujuan untuk mengidentifikasi profil sensori cheese tea menggunakan metode uji sensosri yang relatif baru yaitu check all that apply (CATA) dan ideal profiling method (IPM), serta melakukan profiling emosi dengan metode emotional sensory mapping (ESM).

\section{BAHAN DAN METODE}

\section{Bahan}

Cheese tea jenis black tea (dengan 5 merek berbeda) diperoleh dari vendor yang berada di pusat belanja yang berada di Bogor. Sampel yang digunakan dapat dilihat pada Tabel 1. Bahan lain yang digunakan adalah air mineral dan cracker.

Alat yang digunakan dalam penelitian sensori ini adalah kertas label, baki, alat tulis, kertas kuesioner, aplikasi XLSTAT dan aplikasi Senstools.Net. Penga- 
cakan sampel dilakukan dengan Program Sensehub (https://sensehub.sensolution.id/beranda/) dengan William Latin Square untuk mengurangi efek carry over (MacFie et al. 1989).

Tabel 1. Variasi merek produk cheese tea

\begin{tabular}{cclc}
\hline No & Sampel & \multicolumn{1}{c}{ Merek } & $\begin{array}{c}\text { Kode } \\
\text { Produk }\end{array}$ \\
\hline 1 & Black cheese tea & $\begin{array}{l}\text { Franchise vendor A di } \\
\text { Bogor }\end{array}$ & $\mathrm{A}$ \\
2 & Black cheese tea & $\begin{array}{l}\text { Franchise vendor B di } \\
\text { Bogor }\end{array}$ & $\mathrm{B}$ \\
3 & Black cheese tea & $\begin{array}{l}\text { Franchise vendor C di } \\
\text { Bogor }\end{array}$ & $\mathrm{C}$ \\
4 & Black cheese tea & $\begin{array}{l}\text { Franchise vendor D di } \\
\text { Bogor }\end{array}$ & $\mathrm{D}$ \\
5 & Black cheese tea & $\begin{array}{l}\text { Franchise vendor E di } \\
\text { Bogor }\end{array}$ & E \\
\hline
\end{tabular}

\section{Prosedur penelitian}

Penelitian dilakukan melalui dua tahap, tahap pertama adalah pengujian sampel cheese tea dengan CATA untuk profiling sensori dan emosi. Tahap kedua dilakukan dengan metode IPM untuk profiling sensori dan optimasi produk. Alur penelitian dapat dilihat pada Gambar 1.

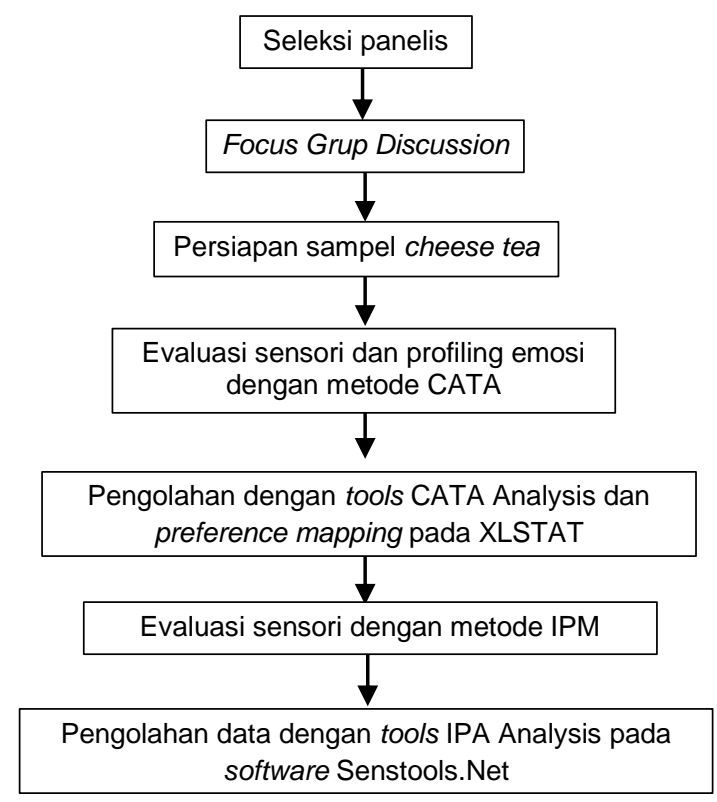

Gambar 1. Diagram alir prosedur penelitian

\section{Seleksi panelis}

Kuesioner pada tahap pemilihan panelis dirancang untuk mengumpulkan informasi latar belakang konsumen termasuk jenis kelamin, usia, dan intensitas konsumsi panelis pada produk cheese tea dalam satu minggu (Eertmans et al. 2006). Panelis yang terpilih adalah panelis yang memiliki frekuensi konsumsi minuman cheese tea minimum 1 sampai 2 kali dalam satu minggu. Karena produk ini relatif baru sehingga panelis memiliki yang masuk kategori berusia diantara 19-25 tahun dan 60\% dari panelis terpilih berjenis kelamin perempuan. Panelis terpilih setelah seleksi adalah 30 orang untuk setiap uji (Lawless and Haymann 2010).

\section{Focus grup discussion (FGD)}

FGD dilakukan oleh 15 orang. FGD dilakukan untuk menentukan atribut sensori yang terdapat pada produk minuman cheese tea dan atribut emosi yang ditimbulkan saat mengonsumsi produk cheese tea. Atribut yang terpilih digunakan untuk pengujian CATA dan ESM.

\section{Persiapan sampel cheese tea}

Persiapan sampel dimulai dengan mencampur teh dan keju dengan perbandingan 5:1 dalam gelas. Sebanyak $40 \mathrm{~mL}$ sampel dituangkan ke dalam gelas plastik $50 \mathrm{~mL}$. Suhu cheese tea saat disajikan berkisar antara 8 hingga $15^{\circ} \mathrm{C}$.

\section{Evaluasi sensori dan profiling emosi dengan CATA}

Panelis diberikan set sampel masing-masing \pm 40 $\mathrm{mL}$ dan satu gelas air mineral $240 \mathrm{~mL}$ dan cracker sebagai penetral mulut untuk menghilangkan aftertaste (Belusso et al. 2016). Panelis diberi pertanyaan tentang persepsi ideal profil sensori cheese tea dengan memberikan tanda centang pada atribut sensorik yang dianggap mampu menggambarkan cheese tea sebelum mencicipi sampel. Atribut sensorik dan emosional yang digunakan diperoleh melalui hasil FGD. Panelis diberi satu set sampel masing-masing $\pm 40 \mathrm{~mL}$ dan satu gelas air mineral $240 \mathrm{~mL}$ dan cracker sebagai penetral. Panelis diminta untuk menilai sampel dengan skala preferensi 7 poin $(1=$ sangat tidak suka, hingga $7=$ sangat suka). Panelis menilai atribut sensorik apa saja yang dirasakan pada sampel dan memberi tanda ceklis pada atribut yang dirasakan (Lobo et al. 2021). Para panelis juga diminta untuk menilai emosi apa yang dirasakan saat mengonsumsi sampel dengan memberi tanda centang pada emosi yang mereka rasakan. Penilaian masing-masing sampel diisi pada lembar kuesioner yang sama.

\section{Pengolahan data}

Hasil CATA data yang didapat dengan tools CATA Analysis pada XLSTAT, sedangkan hasil data IPM dengan tools IPA Analysis pada Senstools.Net

\section{HASIL DAN PEMBAHASAN}

\section{Profil sensori produk cheese tea dengan metode check all that apply (CATA)}

Atribut sensori yang umumnya terdapat pada produk cheese tea yaitu atribut pada teh hitam dan keju menurut Kraujalytè et al. (2016) dan Li et al. (2018). Melalui FGD, atribut sensori tersebut dikonsensus dan didapatkanlah 16 atribut sensori (Tabel 2). Profiling produk chesee tea dimulai dengan uji Cochran's Q test dan correspondence analysis (Sourial et al. 2010). Hasil uji Cochran's Q test produk cheese tea (Tabel 2) menghasilkan p-value yang menunjukkan perbandingan setiap 
sampel produk pada setiap atribut sensori dan apabila nilai p-value dibawah nilai signifikasi 5\% maka disimpulkan atribut tersebut berbeda nyata dari atribut lainnya (Meyners et al. 2013). Berdasarkan hasil uji Cochran's $\mathrm{Q}$ test, seluruh atribut sensori masing-masing produk berbeda nyata pada signifikansi $5 \%$ kecuali atribut fermented aroma, sweet aroma, dan astringent.

Correspondence analysis selanjutnya merepresentasikan produk ideal dan produk uji ke dalam sebuah peta biplot sesuai dengan atribut sensori yang dimiliki (Meyners et al. 2013). Gambar 2 menunjukkan korelasi antara produk ideal menurut panelis dengan kelima produk berdasarkan atribut yang diuji. Produk ideal berdasarkan peta biplot yaitu memiliki cheesy aroma, creamy mouthfeel, dan salty taste yang dominan. Terlihat bahwa tidak ada produk yang memiliki profil sensori seperti produk ideal atau setidaknya berada pada kuadran yang sama dengan produk ideal. Produk A memiliki atribut floral flavour yang paling dominan dan produk ini letaknya paling jauh dari titik ideal sedangkan yang titiknya paling dekat ialah produk $\mathrm{C}$ dan $\mathrm{D}$ yang memiliki karakteristik atribut flavour fermented yang dominan.

Tabel 2. Cochran's $Q$ test atribut sensori cheese tea

\begin{tabular}{|c|c|c|c|c|c|c|}
\hline Atribut & p-value & $\mathbf{A}$ & B & $\mathbf{C}$ & D & $\mathbf{E}$ \\
\hline Roasted aroma & 0.000 & $0.267(a)$ & $0.300(a b)$ & $0.600(b)$ & $0.400(a b)$ & $0.100(a)$ \\
\hline Sweet aroma & 0.206 & 0.367 (a) & 0.367 (a) & $0.600(a)$ & $0.400(a)$ & $0.500(a)$ \\
\hline Milky aroma & 0.009 & $0.300(a)$ & $0.500(a b)$ & $0.533(a b)$ & $0.600(a b)$ & $0.700(b)$ \\
\hline Cheesy aroma & 0.018 & 0.100 (a) & $0.233(a b)$ & $0.400(a b)$ & $0.467(b)$ & $0.333(a b)$ \\
\hline Fermented flavor & 0.376 & 0.200 (a) & $0.233(\mathrm{a})$ & 0.367 (a) & $0.333(\mathrm{a})$ & $0.200(a)$ \\
\hline Floral flavor & 0.000 & $0.700(b)$ & $0.233(a)$ & $0.200(a)$ & 0.267 (a) & 0.267 (a) \\
\hline Bitter taste & 0.000 & $0.200(a b)$ & $0.433(b)$ & $0.300(a b)$ & $0.400(b)$ & $0(a)$ \\
\hline Sweet taste & 0.001 & $0.333(a)$ & $0.800(b)$ & $0.633(a b)$ & $0.800(b)$ & $0.700(b)$ \\
\hline Milky taste & 0.009 & 0.367 (a) & $0.667(a b)$ & $0.633(a b)$ & 0.767 (b) & $0.733(b)$ \\
\hline Umami & 0.009 & $0.333(a b)$ & $0.233(a)$ & $0.567(b)$ & $0.200(a)$ & $0.367(a b)$ \\
\hline Salty taste & 0.001 & $0.133(a)$ & $0.100(a)$ & $0.500(b)$ & 0.167 (a) & 0.167 (a) \\
\hline Astringent & 0.161 & 0.367 (a) & 0.200 (a) & 0.267 (a) & $0.333(a)$ & $0.133(a)$ \\
\hline Viscosity mouthfeel & 0.000 & 0.067 (a) & $0.233(\mathrm{ab})$ & 0.467 (b) & 0.467 (b) & 0.067 (a) \\
\hline Creamy mouthfeel & 0.000 & $0.100(a)$ & 0.167 (a) & $0.633(b)$ & $0.700(b)$ & $0.367(a b)$ \\
\hline Plain mouthfeel & 0.011 & $0.500(a)$ & $0.433(a)$ & 0.167 (a) & 0.167 (a) & $0.400(a)$ \\
\hline Watery mouthfeel & 0.000 & $0.667(\mathrm{c})$ & $0.500(\mathrm{bc})$ & $0.133(\mathrm{a})$ & $0.200(a b)$ & $0.633(\mathrm{c})$ \\
\hline
\end{tabular}

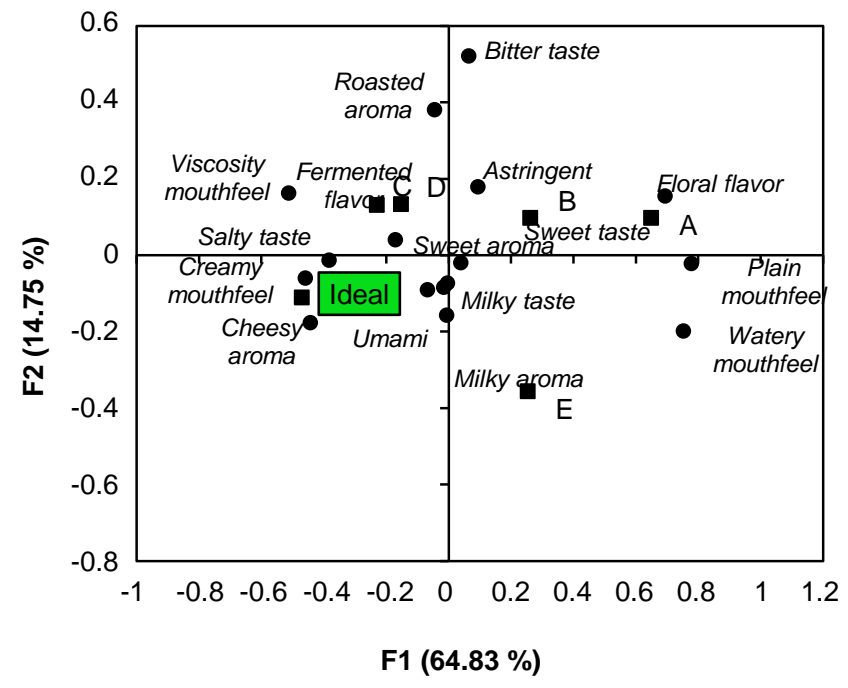

-Attributes $\square$ Products

Gambar 2. Symmetric plot representasi profil sensori produk cheese tea

Produk E berada paling dekat dengan titik atribut milky aroma sedangkan produk B paling dekat dengan titik atribut astringent. Dirangkum hasil principal coordinates analysis (PCA, Gambar 3) menunjukkan bahwa produk cheese tea yang paling disukai konsumen ialah produk dengan atribut sweet aroma, milky aroma, cheesy aroma, milky taste, dan sweet taste.

Correspondence analysis selanjutnya merepresentasikan produk ideal dan produk uji ke dalam sebuah peta biplot sesuai dengan atribut sensori yang dimiliki (Ismawan, 2015; Meyners et al. 2013). Gambar 2 menunjukkan korelasi antara produk ideal menurut panelis dengan kelima produk berdasarkan atribut yang diuji. Produk ideal berdasarkan peta biplot yaitu memiliki cheesy aroma, creamy mouthfeel, dan salty taste yang dominan.

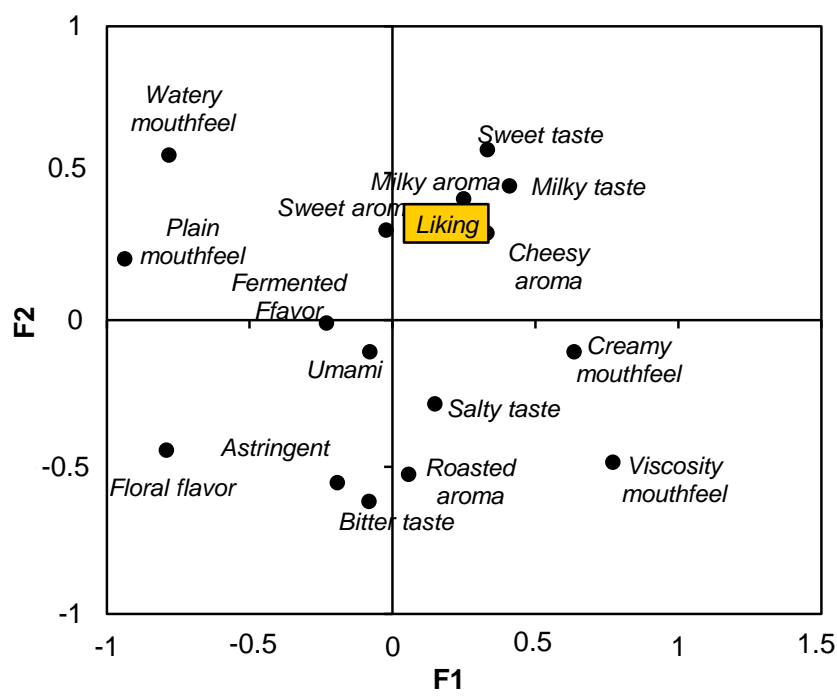

Gambar 3. Korelasi atribut sensori dengan kesukaan

Terlihat bahwa tidak ada produk yang memiliki profil sensori seperti produk ideal atau setidaknya berada pada kuadran yang sama dengan produk ideal. Produk A 
memiliki atribut floral flavour yang paling dominan dan produk ini letaknya paling jauh dari titik ideal. Posisi yang titiknya paling dekat ialah produk $\mathrm{C}$ dan $\mathrm{D}$ yang memiliki karakteristik atribut flavour fermented yang dominan. Produk E berada paling dekat dengan titik atribut milky aroma sedangkan produk B paling dekat dengan titik atribut astringent. Dirangkum hasil principal coordinates analysis (PCA, Gambar 3) menunjukkan bahwa produk cheese tea yang paling disukai konsumen ialah produk dengan atribut sweet aroma, milky aroma, cheesy aroma, milky taste dan sweet taste.

\section{Peta kesukaan panelis terhadap produk cheese tea}

Peta kesukaan panelis dapat dilihat dengan preference mapping. Gambar 4 terlihat bahwa produk D mendapatkan presentase countour plot paling tinggi daripada produk lain yaitu $100 \%$. Hal ini menunjukkan bahwa semua panelis memberikan nilai kesukaan diatas ratarata untuk produk ini. Produk A persentase countour plotnya $0 \%$ yang berarti tidak ada panelis yang memberi nilai kesukaan diatas rata-rata pada produk ini. Pada produk B, sebanyak 33\% panelis menilai produk memiliki nilai kesukaan diatas rata-rata. Produk C dan E mendapatkan persentase sebesar 67 dan 33\%. Peta kesukaan panelis terhadap atribut menunjukkan bahwa atribut sweet taste, milky taste, milky aroma, dan cheesy aroma berada pada countour plot berwarna merah yang berarti memiliki persentase tertinggi panelis yang menilai atribut tersebut memiliki kesukaan diatas rata-rata (80$100 \%$ ). Hasil ini sesuai dengan hasil PCA yang menunjukkan bahwa produk cheese tea yang paling disukai konsumen ialah produk dengan atribut sweet aroma, milky aroma, cheesy aroma, milky taste dan sweet taste.

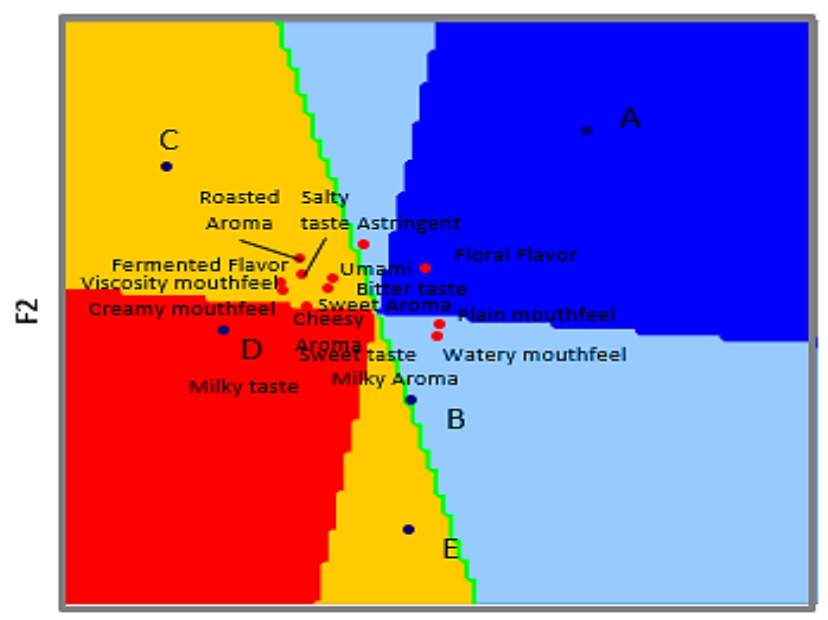

F1

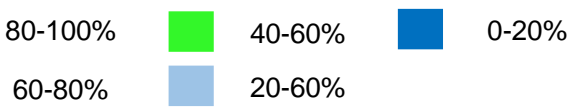

Keterangan: Persentase contour plot $A=0 \%, B=33 \%, C=67 \%, D=$ $100 \%, E=33 \%$

Gambar 4. Peta kesukaan panelis terhadap produk cheese tea

\section{Identifikasi atribut sensori untuk pengembangan produk cheese tea}

Identifikasi atribut sensori untuk pengembangan produk dilakukan dengan penalty analysis (Tabel 3). Penalty analysis pada Tabel 3 didasarkan pada respon konsumen terhadap produk dibandingkan dengan produk ideal yang digunakan untuk mengidentifikasi atribut yang berpengaruh terhadap peningkatan/penurunan kesukaan (hedonik) yang kemudian digunakan untuk optimasi produk (Ares et al. 2014). Tekstur dan mouthfeel sangat berperanan terhadap kesukaan (Szczesniak et al. 1975). Analisis ini terbagi menjadi tiga yaitu analisis atribut sensori must have, nice to have dan must not have (Gambar 5 dan 6). Atribut sensori must have adalah atribut sensori yang tidak ditemukan pada produk nyata padahal atribut sensori tersebut diinginkan oleh panelis pada produk ideal (Meyners et al. 2013). Atribut must have juga dapat dilihat dari Gambar 5 yaitu semakin tinggi nilai koordinat $\mathrm{X}(\% \mathrm{P}(\mathrm{No}) \mid(\mathrm{Yes}))$ dan $\mathrm{Y}$ (mean drops) atau posisi atribut sensori semakin berada di atas kanan grafik, maka semakin baik atribut sensori tersebut untuk dimiliki (must have). Hal ini menunjukkan bahwa cheesy aroma, milky taste, dan creamy mouthfeel merupakan atribut must have (Tabel 3). Suatu atribut sensori berpotensi menjadi atribut sensori must have apabila atribut sensori tersebut memiliki kondisi $\mathrm{P}(\mathrm{No}) \mid$ (Yes) lebih dari $20 \%$ dan nilai mean drops positif.

Tabel 3. Rangkuman penalty analysis

\begin{tabular}{|c|c|c|}
\hline Must have & Nice to have & Must not have \\
\hline $\begin{array}{c}\text { Cheesy aroma } \\
\text { Milky taste }\end{array}$ & & $\begin{array}{c}\text { Floral flavor } \\
\text { Plain mouthfeel }\end{array}$ \\
\hline
\end{tabular}

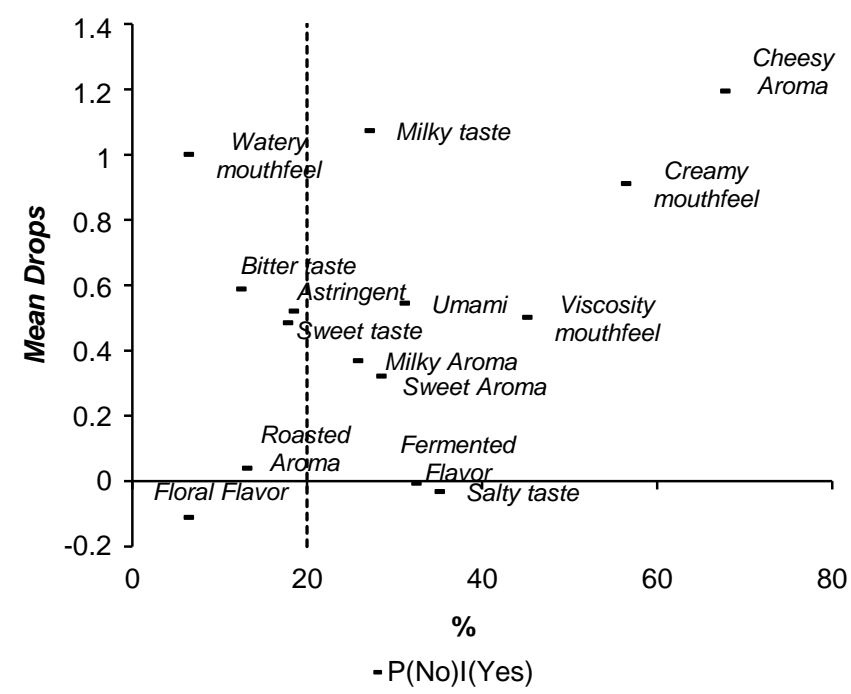

Gambar 5. Analisis atribut must have

\section{Profil emosi produk cheese tea}

Hasil Cochran's $Q$ test pada Tabel 4 menunjukkan bahwa atribut emosi menarik, kecewa, menyesal, senang, dan puas pada masing-masing produk berbeda nyata pada taraf signifikansi 5\% sedangkan atribut tenang, bosan, dan datar tidak berbeda nyata. Gambar 7 merupakan grafik yang menunjukkan atribut emosi yang 
dimiliki oleh produk cheese tea. Menurut grafik tersebut, produk E adalah menghasilkan emosi datar yang paling dominan. Produk B dominan emosi senang, produk $\mathrm{C}$ dominan emosi menyesal, produk $\mathrm{D}$ dominan atribut emosi puas. Produk A menghasilkan emosi kecewa yang dominan.

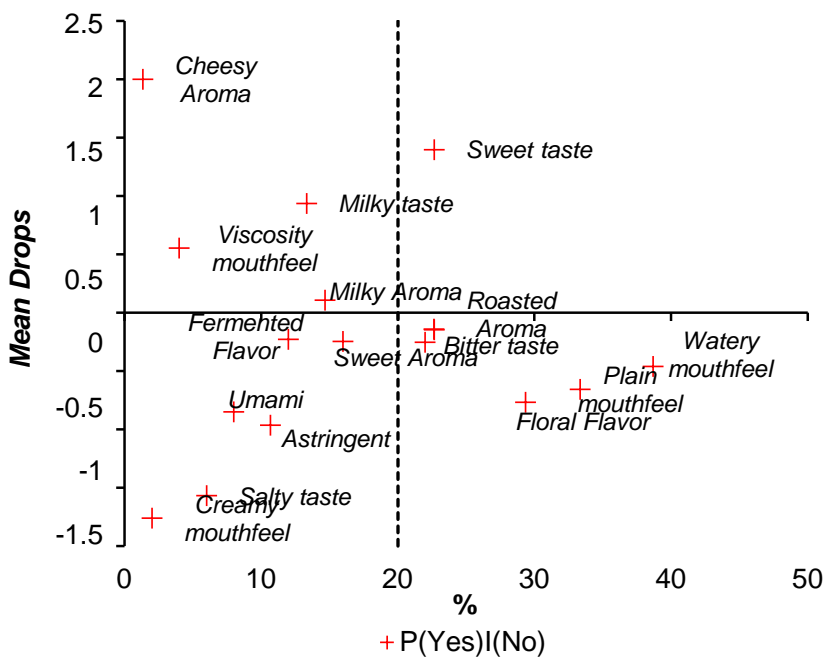

Gambar 6. Analisis atribut nice to have dan must not have

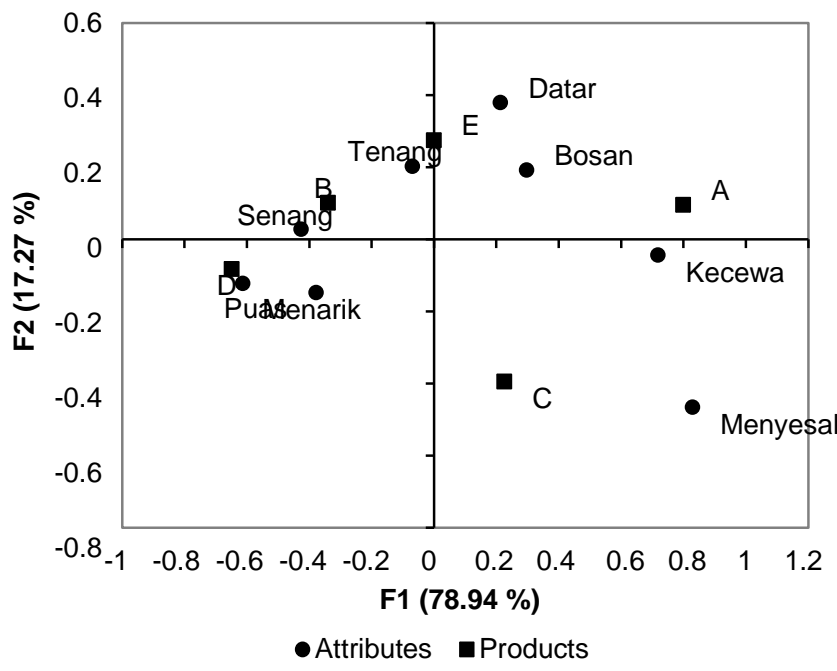

Gambar 7. Symmetric plot representasi profil emosi produk cheese tea

Hasil PCA (Gambar 8) menunjukkan bahwa produk cheese tea yang disukai berada dekat dengan emosi tenang sedangkan produk yang tidak disukai memiliki atribut emosi yang berseberangan dan berjarak sangat jauh dari produk yang disukai (titik kuning), yaitu menyesal, bosan, datar, dan kecewa. Hal ini sesuai dengan teori yang menyatakan bahwa kita akan tertarik terhadap produk yang menghasilkan emosi positif (Presscott 2017).

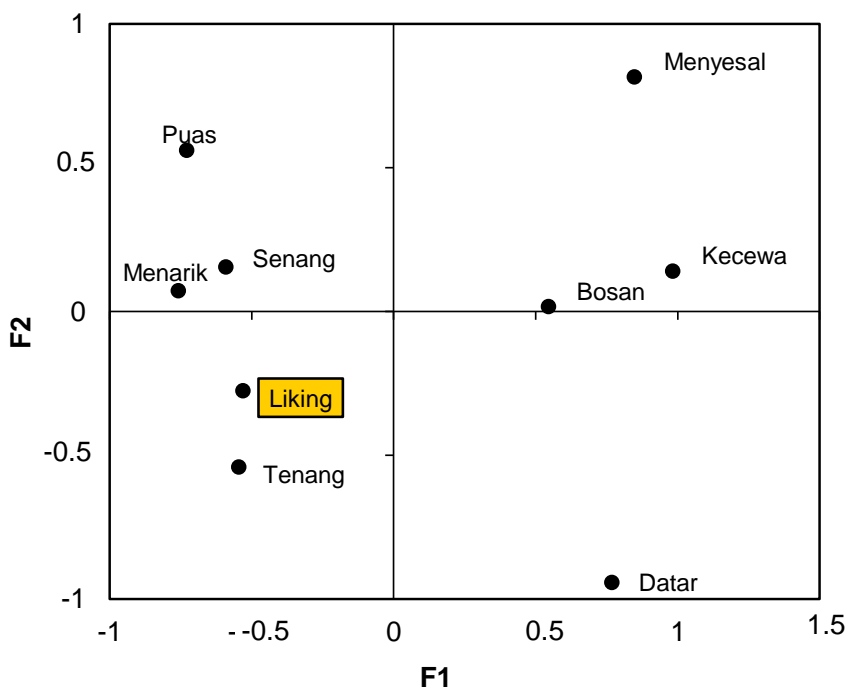

Gambar 8. Grafik korelasi atribut sensori dengan kesukaan

Korelasi emosi dan atribut sensori produk cheese tea

Berdasarkan hasil correspondence analysis untuk profil sensori (Gambar 2) dan profil emosi (Gambar 7), dapat disimpulkan profil sensori dan emosi dominan dari setiap produk. Produk A memiliki atribut floral flavour dan emosi kecewa yang dominan. Produk B dominan atribut sensori astringent dan emosi senang. Produk C dominan atribut fermented flavour dan emosi menyesal. Produk D dominan atribut fermented flavour dan emosi puas. Produk E dominan atribut milky aroma dan emosi kecewa. Semua hasil tersebut dapat dilihat pada Tabel 5.

\section{Optimasi produk cheese tea dengan metode (ideal} profiling method (IPM)

Atribut yang diuji dalam metode ini ialah atribut yang termasuk kategori must have pada uji CATA yang terdapat pada Tabel 3 (cheesy aroma, milky taste, creamy mouthfeel) dan 6 atribut yang tidak termasuk kategori must not have pada Tabel 3 yang dipilih acak (salty taste, umami, sweet taste, roasted aroma, milky aroma, viscosity mouthfeel, milky aroma). Optimasi produk yang dilakukan, sebelumnya, harus dievaluasi terlebih dahulu apakah panelis mengasosiasikan produk sebagai produk yang homogen atau dalam hal ini produk tersebut harus memiliki "one single ideal". Jika konsumen tidak menilai produk dalam one single ideal maka produk tersebut perlu dioptimasi secara terpisah (Worch et al. 2012).

Tabel 4. Cochran's $Q$ test atribut sensori cheese tea

\begin{tabular}{|c|c|c|c|c|c|c|}
\hline Atribut & p-values & $\mathbf{A}$ & B & $\mathbf{C}$ & D & $\bar{E}$ \\
\hline Menarik & 0.003 & $0.133(a)$ & $0.467(a b)$ & $0.400(a b)$ & 0.600 (b) & $0.300(a b)$ \\
\hline Datar & 0.083 & 0.367 (a) & $0.233(\mathrm{a})$ & $0.100(a)$ & 0.167 (a) & 0.367 (a) \\
\hline Kecewa & 0.001 & 0.467 (b) & 0.100 (a) & $0.300(a b)$ & $0.033(\mathrm{a})$ & $0.200(a b)$ \\
\hline Menyesal & 0.000 & $0.267(\mathrm{bc})$ & $0.033(a b)$ & 0.300 (c) & $0(a)$ & $0.067(a b c)$ \\
\hline Tenang & 0.835 & $0.133(a)$ & $0.167(\mathrm{a})$ & 0.067 (a) & $0.133(\mathrm{a})$ & $0.133(\mathrm{a})$ \\
\hline Bosan & 0.358 & 0.167 (a) & $0.133(a)$ & $0.133(a)$ & $0.033(\mathrm{a})$ & 0.200 (a) \\
\hline Senang & 0.019 & $0.033(a)$ & $0.333(b)$ & $0.200(a b)$ & $0.300(a b)$ & $0.267(a b)$ \\
\hline Puas & 0.002 & $0(\mathrm{a})$ & $0.233(\mathrm{ab})$ & $0.167(a b)$ & $0.367(\mathrm{~b})$ & $0.167(a b)$ \\
\hline
\end{tabular}


Tabel 5. Rangkuman atribut dominan produk cheese tea

\begin{tabular}{ccc}
\hline \multirow{2}{*}{ Produk } & \multicolumn{2}{c}{ Atribut } \\
\cline { 2 - 3 } & Sensori & Emosi \\
\hline A & Floral flavour & Kecewa \\
B & Astringent & Senang \\
C & Fermented flavour & Menyesal \\
D & Fermented flavour & Puas \\
E & Milky aroma & Kecewa \\
\hline
\end{tabular}

Gambar 9 telihat bahwa area lingkaran dari setiap produk berada pada lokasi yang berdekatan dan saling timpang tindih yaitu di pojok kiri atas grafik sehingga dapat disimpulkan setiap produk memiliki one single ideal. Hasil tersebut juga didukung dengan tidak adanya nilai p-value pada tabel Hotteling $\mathrm{T} \neg 2$ test (Tabel 5) yang kurang dari taraf signifikansi $5 \%$.

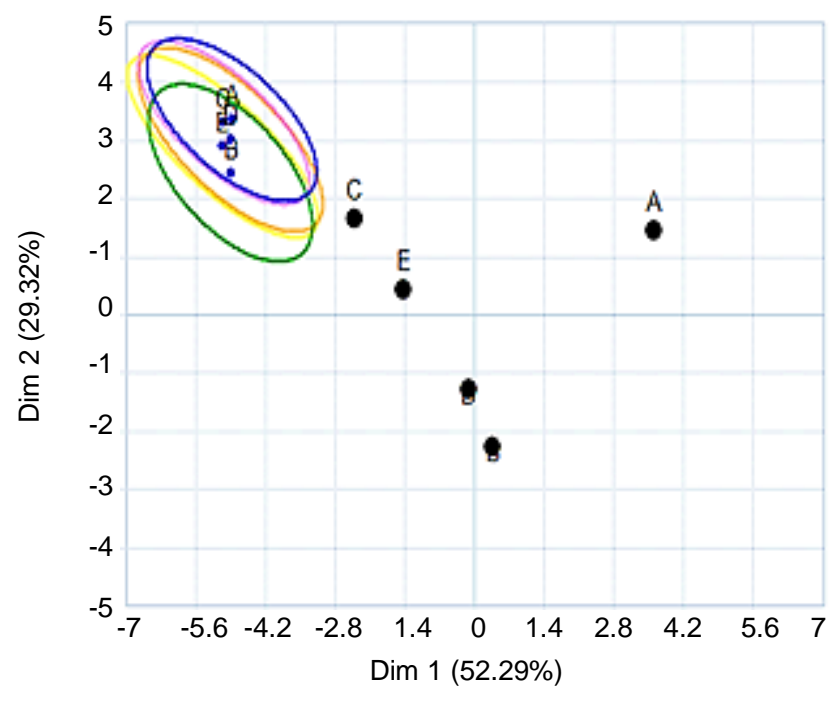

Gambar 9. Confidence ellipses untuk mengecek single/ multiple ideal dari produk

Gambar 10 dapat terlihat bahwa produk yang paling mendekati daerah peta paling gelap ialah produk $\mathrm{C}$ dan E (paling mendekati karakteristik produk ideal). Profil sensori dari produk ideal juga dapat dilihat pada Gambar 11. Pada gambar tersebut, profil sensori dari produk ideal dibandingkan dengan setiap profil dari produk. Produk $\mathrm{C}$ berada paling dekat sementara produk A paling jauh dari produk ideal.

Intensitas atribut rata-rata dari setiap produk dan intensitas ideal rata-rata dapat dilihat pada Tabel 6 . Panduan untuk melakukan optimasi produk dapat dilihat melalui Gambar 12. Grafik dengan skala berwarna merah menunjukkan bahwa intensitas atribut terlalu besar sehingga perlu diturunkan sedangkan skala berwarna hijau menunjukkan intensitas atribut tersebut terlalu kecil sehingga perlu ditingkatkan. Mengambil contoh panduan optimasi untuk produk $\mathrm{C}$ (paling dekat dengan karakteristik produk ideal) dan produk A (paling jauh dari karakteristik produk ideal ideal). Produk C membutuhkan tentunya akan membutuhkan lebih sedikit optimasi dibandingkan produk A. Produk C (Gambar 12 B), atribut creamy mouthfeel, viscosity mouthfeel, dan cheese flavor perlu ditingkatkan untuk mengoptimasi produk. Menurunkan intensitas atribut roasted aroma, sweet taste, milky aroma, milky taste, salty taste, dan umami juga diperlukan untuk optimasi, sementara atribut sudah memiliki intensitas yang ideal.

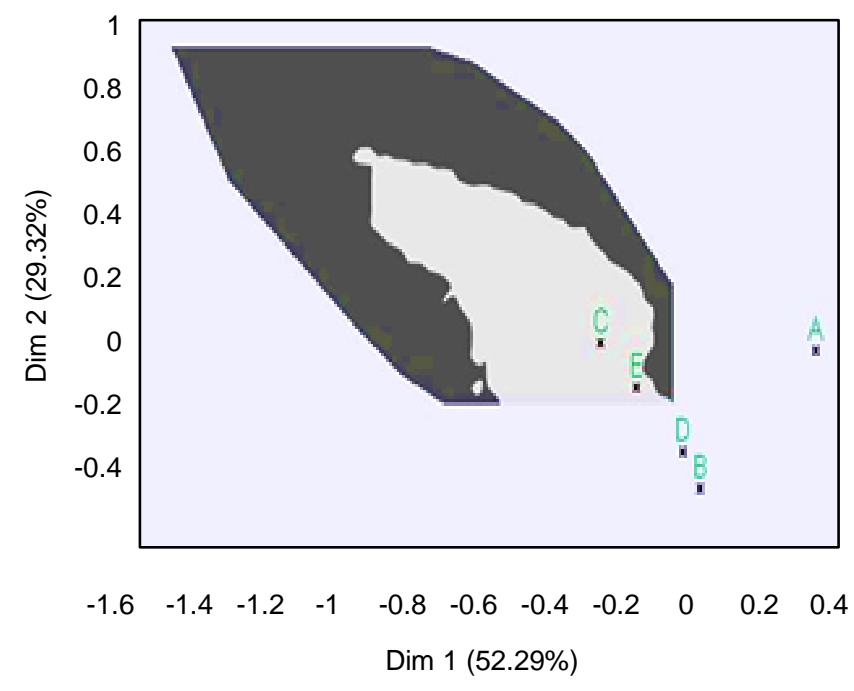

Gambar 10. Ideal Mapping

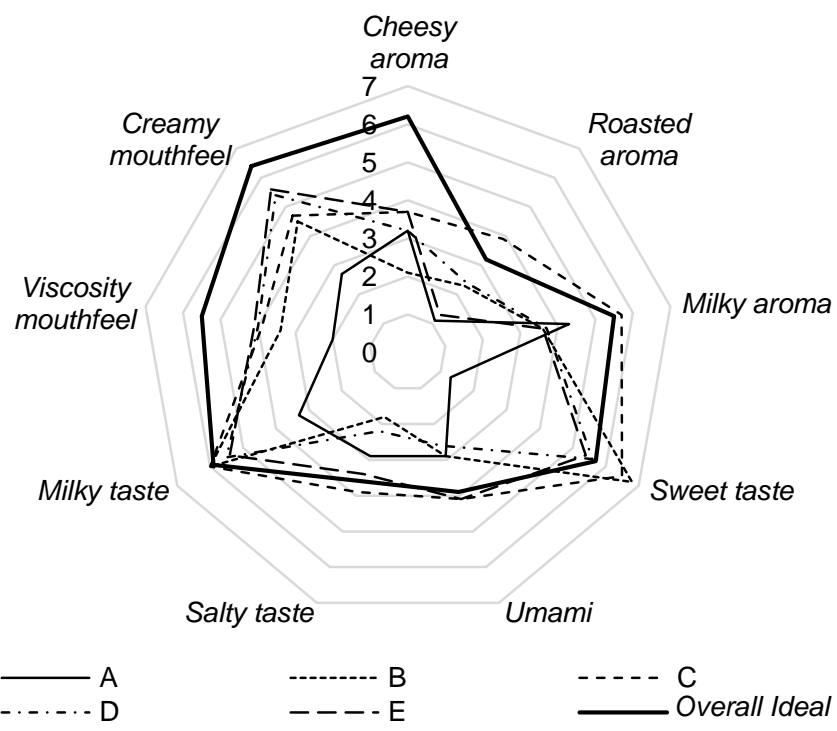

Gambar 11. Perbandingan karakteristik sensori produk ideal dengan produk uji

Tabel 6. Hotteling T2 Test

\begin{tabular}{cccccc}
\hline & A & B & C & D & E \\
\hline A & 1 & 0.33 & 0.96 & 0.83 & 0.59 \\
B & 0.33 & 1 & 0.42 & 0.65 & 0.81 \\
C & 0.96 & 0.42 & 1 & 0.92 & 0.73 \\
D & 0.83 & 0.65 & 0.92 & 1 & 0.92 \\
E & 0.59 & 0.81 & 0.73 & 0.92 & 1 \\
\hline
\end{tabular}

\section{KESIMPULAN}

Hasil penelitian karakterisasi produk cheese tea, telah dihasilkan profil sensori dan emosi secara detail serta melihat korelasi dan pengaruhnya terhadap kesu- 
kaan panelis. Produk cheese tea yang paling disukai konsumen ialah produk dengan atribut sweet aroma, milky aroma, cheesy aroma, milky taste dan sweet taste serta atribut emosi tenang yang dominan. Produk cheese tea $\mathrm{C}$ ialah produk yang paling mendekati karakteristik produk ideal. Metode IPM dapat digunakan untuk mengoptimalkan produk agar memiliki intensitas atribut yang mendekati atau sama dengan intensitas atribut produk ideal. Produk cheese tea $\mathrm{C}$ juga menjadi produk yang paling mendekati karakteristik produk ideal dilihat dari ideal mapping. Optimalisasi produk cheese tea $\mathrm{C}$ tersebut, intensitas atribut creamy mouthfeel, viscosity mouthfeel, dan cheese aroma perlu ditingkatkan serta intensitas atribut roasted aroma, milky aroma, umami, salty taste, milky taste dan sweet taste perlu diturunkan.
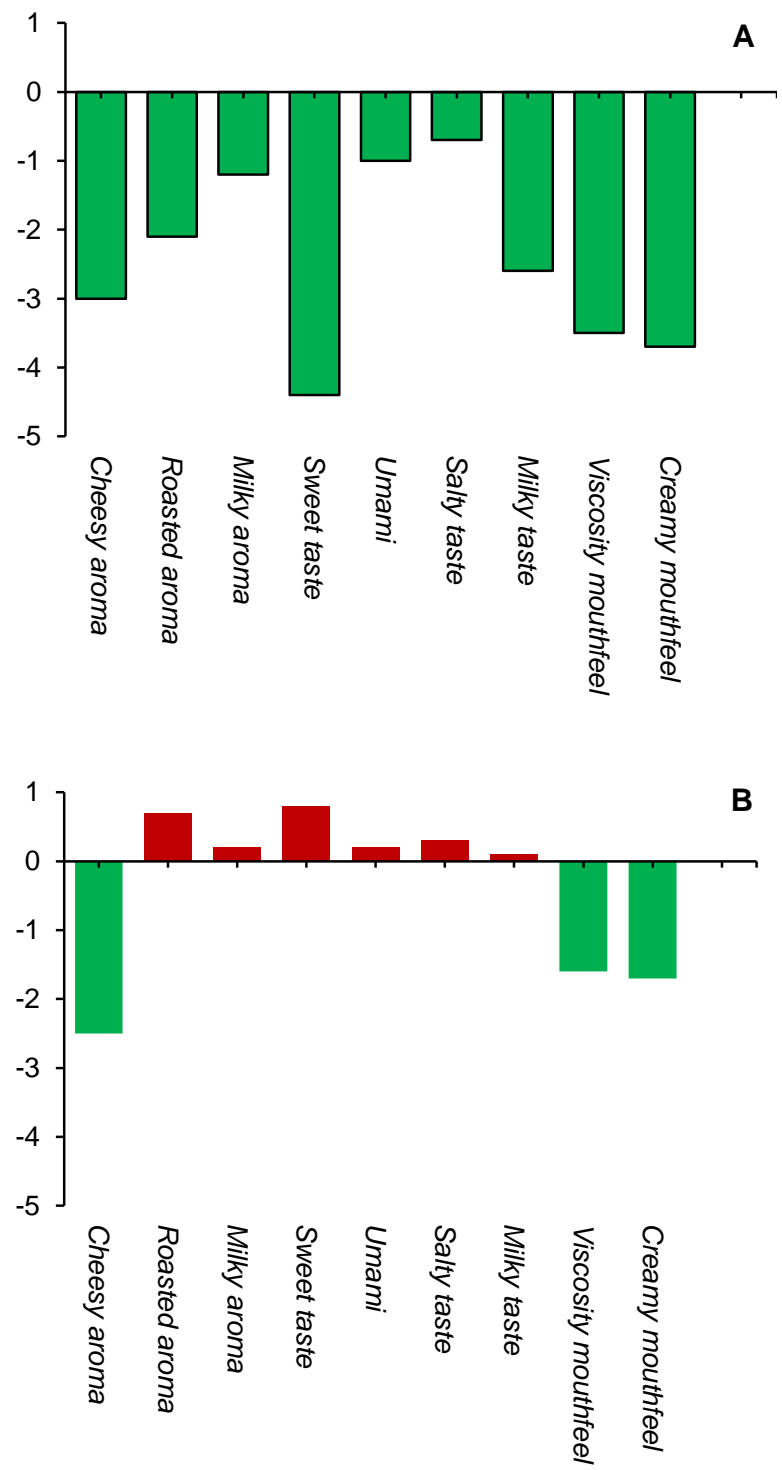

Gambar 12. Grafik panduan peningkatan/penurunan atribut untuk produk $A(A)$ dan produk $C(B)$

\section{DAFTAR PUSTAKA}

Ares G, Barreio C, Deliza R, Gimenez A, dan Gambaro A. 2010. Application of a check-all-that-apply ques- tion to the development of chocolate milk deserts. J Sens Stud 25(S1): 67-86. DOI: 10.1111/j.1745459X.2010.00290.x.

Ares G, Dauber C, Fernandez E, Gimenez A, Varela P. 2014. Penalty analysis based on CATA questions to identify drivers of liking and directions for product reformulation. Food Qual Prefer 32(a): 65-76. DOI: 10.1016/j.foodqual.2013.05.014.

Belusso AC, Nogueira BA, Breda LS, Mitterer-Dalto ML. 2016. Check-all-that-apply (CATA) as an instrument for development of fish products. Food Sci Technol 36(2): 275-281. DOI: 10.1590/1678457X.0026.

Dooley L, Lee YS, Meullenet JF. 2010. The application od check-all-that apply (CATA) consumer profiling to preference mapping of vanilla ice cream and its comparison to classical external preference mapping. Food Qual Prefer 21(4): 395-401. DOI: 10.1016/j.foodqual.2009.10.002

Eertmans A, Victoir A, Notelaers G, Vansant G, Van den Bergh O. 2006. The food choice questionnaire: Factorial invariant over western urban populations?. Food Qual Prefer 17(5): 344-352. DOI: 10.1016/j. foodqual.2005.03.016.

Faye P, Bremaud D, Teillet E, Courcoux P, Giboreau A dan Nicod H. 2006. An alternative to external preference mapping based on consumer perceptive mapping. Food Qual Prefer 17(7-8): 604-614. DOI: 10.1016/j.foodqual.2006.05.006.

Ismawan F. 2015. Hasil ekstraksi algoritma principal component analysis (PCA) untuk pengenalan wajah dengan bahasa pemograman Java Eclipse IDE. J Sisfotek Global 5(1): 26-30.

Jiang Y, King JM., Prinyawiwatkul W. 2014. A review of measurement and relationships between food, eating behavior and emotion. Trends Food Sci Technol 36(1): 15-28. DOI: 10.1016/j.tifs.2013.12. 005.

Kraujalytė V, Pelvan E, Alasalvar C. 2016. Volatile compounds and sensory characteristics of various instant teas produced from black tea, Food Chem 194: 864-872. DOI: 10.1016/j.foodchem.2015.08. 051.

Li H, Luo L, Ma M, Zeng, L. 2018. Characterization of volatile compounds and sensory analysis of jasmine scented black tea produced by different scenting processes. J Food Sci 83 (11): 2718-2732. DOI: 10. 1111/1750-3841.14340.

Lobo AP, Bedriñana RP, Madrera RR, Valles BS, 2021. Aromatic, olfactometric and consumer description of sweet ciders obtained by cryo-extraction. Food Chem 338: 127829. DO: 10.1016/j.foodchem.2020. 127829 .

Lawless HT, Heymann H. 2010. Sensory Evaluation of Food: Principles and Practices (Second Edi). New York (US). Springer Science+Bussines Media. DOI: 10.1007/978-1-4419-6488-5_3. 
MacFie HJ, Bratchell N, Greenhoff K, Vallis LV. 1989. Designs to balance the effect of order of presentation and first-order carry-over effects in hall tests. J Sens Stud 4(2): 129-148. DOI: 10.1111/j.1745459X.1989.tb00463.x.

Meiselman HL. 2015. A review of the current state of emotion research in product development. Food Res Int 76(Part 2): 192-199. DOI: 10.1016/j.foodres. 2015.04.015.

Meyners M, Castura JC, Carr BT. 2013. Existing and new approaches for the analysis of CATA data. Food Qual Prefer 30(2): 309-319. DOI: 10.1016/j. foodqual.2013.06.010.

Rahmawati D, Andarwulan N, Lioe HN. 2015. Development of taste and aroma attributes for mayonnaise by quantitative descriptive analysis. J Mutu Pangan 2(2): 80-87.

Reinbach HC, Giacalone D, Ribeiro LM, Bredie WLP, Frøst MB. 2014. Comparison of three sensory profiling methods based on consumer perception: CATA, CATA with intensity and Napping. Food Qual Prefer 32(b): 160-166. DOI: 10.1016/j.food qual.2013.02.004.

Sourial N, Wolfson C, Zhu B, Quail J, Fletcher J, Karunananthan S, Bergman H. 2010. Correspondence analysis is a useful tool to uncover the relationships among categorical variables. J Clin Epidemiol 63(6): 638-646. DOI: 10.1016/j.jclinepi. 2009.08.008.
Szczesniak AS, Loew BL, Skinner EZ. 1975. Consumer texture profile technique. J Food Sci 40(6): 12531256. DOI: 10.1111/j.1365-2621.1975.tb01065.x.

Thomson DMH, Crocker C, Marketo CG. 2010. Linking sensory characteristics to emotions: An example using dark chocolate. Food Qual Prefer 21(8): 1117-1125. DOI: 10.1016/j.foodqual.2010.04.011.

Tseng E. 2018. Cheese tea Could Be the New Bubble Tea-If Americans Get Over the Name.: https:// www.eater.com/2018/9/21/17846630/cheese-teatrend-explained.

Varela P, Ares G, Gimenez A, Gambaro A. 2010. Influence of brand information on consumers expectations and liking of powdered drinks in central location tests. J Food Qual Prefer 21(7): 873880. DOI: 10.1016/j.foodqual.2010.05.012.

Worch T, Le S, Punter P. 2010. How reliable are the consumers? Comparison of sensory profiles from consumers and experts. Food Qual Prefer 21(3): 309-318. DOI: 10.1016/j.foodqual.2009.06.001.

Worch T, Le S, Punter PH, Pagès J. 2012. Ideal profile method (IPM): The ins and outs. Food Qual Prefer 28(1): 45-59. DOI: 10.1016/j.foodqual.2012.08.001.

Worch T, Punter PH. 2014. Rapid sensory profiling techniques: Ideal profile methode as a sensory profiling technique (Eds. Delarue and Lawlor). Food Science, Technology and Nutrition 1: 307-332. Elsevier: Woodhead Publishing, Boca Raton, USA. DOI: $10.1533 / 9781782422587.2 .307$.

JMP-12-20-16-Naskah diterima untuk ditelaah pada 21 Desember 2020 Revisi makalah disetujui untuk dipublikasi pada 4 Februari 2021. Versi Online: http://journal.ipb.ac.id/ index.php/jmpi 